\title{
Standardization of a fluorimetric assay for the determination of tissue angiotensin-converting enzyme activity in rats
}

\footnotetext{
E.M. Oliveira1,2,

R.A.S. Santos ${ }^{3}$ and J.E. Krieger ${ }^{1}$
}

\author{
${ }^{1}$ Laboratório de Genética e Cardiologia M olecular e Departamento de Clínica Médica/ \\ LIM 13, Instituto do Coração, Faculdade de Medicina, Universidade de São Paulo, \\ São Paulo, SP, Brasil \\ ${ }^{2}$ Departamento de Bioquímica, Instituto de Biociências, Universidade Federal do \\ Rio Grande do Sul, Porto Alegre, RS, and Escola de Educação Física, \\ Universidade de São Paulo, São Paulo, SP, Brasil \\ 'Laboratório de Hipertensão, Instituto de Ciências Biológicas, \\ Universidade Federal de Minas Gerais, Belo Horizonte, MG, Brasil
}

\section{Correspondence \\ J.E. Krieger \\ Laboratório de Genética e \\ Cardiologia Molecular \\ Instituto do Coração, FM, USP \\ Av. Dr. Eneas C. Aguiar, 44 \\ 05403-000 São Paulo, SP \\ Brasil \\ Fax: +55-11-3069-5022 \\ E-mail: krieger@ incor.usp.br \\ Research supported by FINEP (No. 6693002300), FAPESP (No. 9546686), CN Pq \\ (No. 520696/95-6) and Fundação \\ E.J. Zerbini. E.M. O liveira is \\ the recipient of a CNPq doctoral \\ fellowship (No. 140621/93-8).}

Received February 24, 1999

Accepted M arch 9, 2000

\section{Abstract}

The tripeptide Hip-His-Leu was used to standardize a fluorimetric method to measure tissue angiotensin-converting enzyme (ACE) activity in rats. The fluorescence of the $o$-phthaldialdehyde-His-Leu adduct was compared in the presence and absence of the homogenate $(25 \mu \mathrm{l})$ to determine whether the homogenate from different tissues interfered with the fluorimetric determination of the His-Leu product. Only homogenates from lung and renal medulla and cortex showed significantly altered fluorescence intensity. To overcome this problem, the homogenate from these tissues were diluted 10 times with assay buffer. The specificity of the assay was demonstrated by the inhibition of ACE activity with $3 \mu \mathrm{M}$ enalaprilat (MK-422). There was a linear relationship between product formation and incubation time for up to $90 \mathrm{~min}$ for homogenates of renal cortex and medulla and liver, for up to $60 \mathrm{~min}$ for ventricles and adrenals and for up to $30 \mathrm{~min}$ for the aorta, lung and atrium homogenates. In addition, there was a linear relationship between product formation and the amount of protein in the homogenates within the following range: lung, 30-600 $\mu \mathrm{g}$; renal cortex and medulla, 40-400 $\mu \mathrm{g}$; atrium and ventricles, 20 $200 \mu \mathrm{g}$; adrenal, 20-100 $\mu \mathrm{g}$; aorta, 5-100 $\mu \mathrm{g}$; liver, 5-25 $\mu \mathrm{g}$. No peptidase activity against the His-Leu product $(31 \mathrm{nmol})$, assayed in borate buffer (BB), was detected in the different homogenates except the liver homogenate, which was inhibited by $0.1 \mathrm{mM} \rho$-chloromercuribenzoic acid. ACE activity in BB was higher than in phosphate buffer (PB) due, at least in part, to a greater hydrolysis of the His-Leu product in PB. ACE activity of lung increased $20 \%$ when BB plus Triton was used. Enzyme activity was stable when the homogenates were stored at $-20^{\circ}$ or $-70^{\circ} \mathrm{C}$ for at least 30 days. These results indicate a condition whereby ACE activity can be easily and efficiently assayed in rat tissue samples homogenized in BB using a fluorimetric method with Hip-His-Leu as a substrate.

\section{Key words}

- Angiotensin-converting enzyme

- ACE activity

- Fluorimetric assay

- Rat tissues 


\section{Introduction}

Angiotensin-converting enzyme (ACE) is a dipeptidyl carboxypeptidase (EC 3.4.15. 1) that inactivates the vasodepressor compound bradykinin and activates the potent vasoconstrictor and growth-promoting substance angiotensin II (Ang II) by removal of the carboxy-terminal dipeptide of angiotensin I (Ang I). The enzyme is present mainly in the lung (1) but also in plasma and other tissues $(2,3)$. At these locations, ACE can influence the production of Ang II and may have important physiological contribution in the maintenance of cardiovascular homeostasis (4). Thus, measurements of ACE activity in tissues combined with molecular biology approaches can provide important information regarding the role of ACE in physiological and pathophysiological mechanisms.

ACE activity has been determined by different methods (1,5-10). In general, measurements of ACE activity are based on the hydrolysis of synthetic tripeptides blocked at the amino terminus $(6,7,10,11)$. Among the synthetic substrates, one of the most used has been hippuryl-L-histidyl-L-leucine (HipHis-Leu). This tripeptide contains the terminal sequence of Ang I and its hydrolysis can be detected by the formation of hippuric acid (1) or by the formation of the dipeptide HisLeu $(8,10)$. The fluorimetric detection of this dipeptide is a method of high sensitivity and is both a reproducible and simple assay for the determination of ACE activity.

In the present study ACE activity in different rat tissues was determined using the fluorimetric assay described by Santos et al. (10) to determine ACE activity in rat serum. Our results indicate that borate buffer (BB) performs better than phosphate buffer (PB), which has been the buffer most frequently used to determine ACE activity $(1,12)$. Moreover, the hydrolysis of the His-Leu dipeptide was shown to be very high in tissues like liver, with a consequent underestimate of
ACE activity levels. The use of $\rho$-chloromercuribenzoic acid (PCMB), a dipeptidase inhibitor, successfully resolves this problem. Taken together, the present study extends the initial work of Santos et al. (10) on the use of this method to determine tissue ACE activity in rat samples.

\section{Material and Methods}

\section{Rat tissues and serum samples}

Normotensive male Wistar and SHR rats (200-250 g) were used and handled according to the NIH guidelines. ACE determination was performed in serum, lung, kidney (cortex and medulla), heart ventricle and atrium, adrenal, liver and aorta. The animals were decapitated and blood was collected without anticoagulant, kept on ice, rapidly centrifuged at $3,000 \mathrm{rpm}$ for $10 \mathrm{~min}$ and stored at $-20^{\circ}$ or $-70^{\circ} \mathrm{C}$. Tissue samples were quickly harvested, rinsed, blotted and homogenized in $0.4 \mathrm{M} \mathrm{BB}$, pH 7.2, containing $0.34 \mathrm{M}$ sucrose and $0.9 \mathrm{M} \mathrm{NaCl}$, and frozen at $-20^{\circ}$ or $-70^{\circ} \mathrm{C}(1 \mathrm{~g}$ tissue: $10 \mathrm{ml}$ buffer $)$ or $0.1 \mathrm{M}$ sodium $\mathrm{PB}, \mathrm{pH} 7.2$, containing $0.34 \mathrm{M}$ sucrose and $0.3 \mathrm{M} \mathrm{NaCl}$. Homogenates were centrifuged at 3,000 rpm for $10 \mathrm{~min}$ and the supernatants frozen at $-20^{\circ}$ or $-70^{\circ} \mathrm{C}$ for fluorimetric assay of ACE activity.

\section{Determination of ACE activity}

ACE activity was determined in rat tissues by the method described by Santos et al. (10) for the detection of ACE activity in plasma and serum. Briefly, serum $(10 \mu \mathrm{l})$ and supernatants from homogenized tissues $(20 \mu 1)$ were incubated with 490 or $480 \mu$ of assay buffer containing $5 \mathrm{mM}$ Hip-His-Leu in $0.4 \mathrm{M}$ sodium $\mathrm{BB}$ and $0.9 \mathrm{M} \mathrm{NaCl}, \mathrm{pH}$ 8.3; sodium $\mathrm{BB}$ with $0.1 \%$ Triton $\mathrm{X}-100$ with $0.9 \mathrm{M} \mathrm{NaCl}, \mathrm{pH} 8.0$, or $0.1 \mathrm{M}$ sodium $\mathrm{PB}$ with $0.3 \mathrm{M} \mathrm{NaCl}, \mathrm{pH} \mathrm{8.0,} \mathrm{for} 15$ or 30 $\min$ at $37^{\circ} \mathrm{C}$. The reaction was stopped by the addition of $1.2 \mathrm{ml}$ of $0.34 \mathrm{~N} \mathrm{NaOH}$. The 
product, His-Leu, was measured fluorimetrically at 365-nm excitation and 495-nm emission with a fluoro-colorimeter (AMINCO) as follows. One hundred $\mu 1$ of $o$-phthaldialdehyde $(20 \mathrm{mg} / \mathrm{ml})$ in methanol was added and after $10 \mathrm{~min}$ the solution was acidified with $200 \mu 13 \mathrm{~N} \mathrm{HCl}$ and centrifuged in a clinical centrifuge at $3,000 \mathrm{rpm}$ for $10 \mathrm{~min}$ at room temperature. To correct for the intrinsic fluorescence of the tissues and serum, time zero blanks (To) were prepared by adding tissue or serum after $\mathrm{NaOH}$. All assays were performed in duplicate or triplicate.

\section{Demonstration of the validity of the enzy- matic assay}

Standard curves for His-Leu were obtained daily. There was a linear relationship between relative fluorescence and His-Leu concentration. Ten $\mu \mathrm{l}$ rat serum or $20 \mu \mathrm{l}$ tissue homogenate ( $1 \mathrm{~g}$ tissue: $10 \mathrm{ml}$ buffer) did not modify the slope of the His-Leu standard curve, except for homogenates from lung, and renal medulla and cortex. To overcome this problem, homogenates from these tissues were diluted ten-fold with the assay buffer. When assays were carried out in sodium PB solution, His-Leu standards were prepared with the same buffer and assayed in parallel.

\section{Demonstration of the specificity of the enzymatic assay}

The specificity of the assay was determined by the inhibition of ACE activity using $3 \mu \mathrm{M}$ enalaprilat (MK-422).

\section{Linearity of the assay with regard to time}

A $20-\mu 1$ sample of homogenized tissue was incubated in assay buffer for up to 120 min (kidney medulla and cortex), $90 \mathrm{~min}$ (liver), $60 \mathrm{~min}$ (ventricle and adrenal) and 30 min (aorta, lung and atrium). The assay was carried out as described above.

\section{Linearity of the assay with regard to protein concentration}

The samples of homogenized tissues were tested within the following range: $30-600 \mu \mathrm{g}$ for lung, 40-800 $\mu \mathrm{g}$ for renal medulla and cortex, 20-200 $\mu \mathrm{g}$ for ventricle, 20-400 for atrium, 20-200 $\mu \mathrm{g}$ for adrenal, 5-100 $\mu \mathrm{g}$ for aorta and 5-25 $\mu \mathrm{g}$ for liver. The homogenates were incubated for different periods of time. The samples were incubated in assay buffer as described above.

\section{Measurement of dipeptidase activity}

To determine the presence of dipeptidase activity in BB and PB $20 \mu \mathrm{l}$ of tissue sample was incubated with $31 \mathrm{nmol} \mathrm{His-Leu} \mathrm{for} 30$ min. The relative fluorescence of the reaction mixture was compared with the value obtained at To as described above. In tissues where dipeptidase activity was detected, the samples were analyzed in the presence of the SH reagent $\mathrm{PCMB}(0.1 \mathrm{mM})$.

\section{Protein determination}

Protein was measured by the method of Bradford (13) using bovine serum albumin as a standard.

\section{Statistical analysis}

Data are reported as means \pm SD. Statistical analysis was performed by the Student $t$-test. $P$ values of less than 0.05 were considered significant.

\section{Results}

We compared the fluorimetric determination of the dipeptide in the presence and absence of homogenate $(25 \mu \mathrm{l})$ to determine whether homogenates from different tissues interfere with the detection of the His-Leu product. The homogenates of renal medulla and cortex and lung significantly altered the 
Figure 1 - Influence of tissue homogenates on the fluorescence of the dipeptide His-Leu. The fluorescence of the dipeptide HisLeu was compared in the presence and absence of the homogenate $(25 \mu \mathrm{l})$. Results are expressed as fluorescence $/ \mathrm{nmol}$ His-Leu. Data represent the mean \pm SD of three independent experiments for SHR (open columns) and Wistar rats (filled columns). ${ }^{*} \mathrm{P}<0.001$ compared to control (Student t-test).

intensity of the fluorescence signal, while the homogenate of other tissues did not. Diluting the homogenate of renal medulla, cortex and lung ten-fold with the assay buffer eliminated the interference (Figure 1).

The specificity of the hydrolysis of HipHis-Leu as a measure of ACE activity was demonstrated by greater than $98 \%$ inhibition of the enzymatic activity by $3 \mu \mathrm{M}$ MK-422 (results not shown).

Production of the dipeptide His-Leu as a function of time of incubation is shown in Figure 2 . The linearity of the assay as a function of time was maintained for up to 90 min for renal medulla and cortex and liver, up to $60 \mathrm{~min}$ for ventricle and adrenal, and up to $30 \mathrm{~min}$ for aorta, lung, and atrium. The linearity of the assay as a function of protein concentration (Figure 3) was maintained within the following range: lung, 30-600 $\mu \mathrm{g}$; renal medulla and cortex, $40-400 \mu \mathrm{g}$; atrium and ventricle, 20-200 $\mu \mathrm{g}$; adrenal, 20-100 $\mu \mathrm{g}$; aorta, 5-100 $\mu \mathrm{g}$; liver, 5-25 $\mu \mathrm{g}$ homogenates. Based on these results, $20 \mu 1$ of the lung and aorta homogenates was incubated for $15 \mathrm{~min}$ while the other tissues were incubated for 30 min to determine ACE activity. These results were obtained for both SHR and Wistar rats.

To investigate the possibility of nonspecific fluorescence development under the assay conditions, the relative fluorescence of the homogenate was evaluated under control conditions (To) and after $1 \mathrm{~h}$ of incubation of tissue homogenate samples from Wistar and SHR rats. This period of time was chosen because it was the maximum used for incubation. No difference between the two conditions was observed, indicating that the stability of the homogenates is maintained under the assay conditions for up to 1 h (results not shown).

To determine whether dipeptidases in the homogenates can hydrolyze His-Leu, destroying the compound that gives the fluorescence to measure ACE activity, the homogenates were incubated for $30 \mathrm{~min}$ with the dipeptide His-Leu. In 0.4 M BB dipeptidase activity was found only in the liver (Table 1) and could be partially blocked by

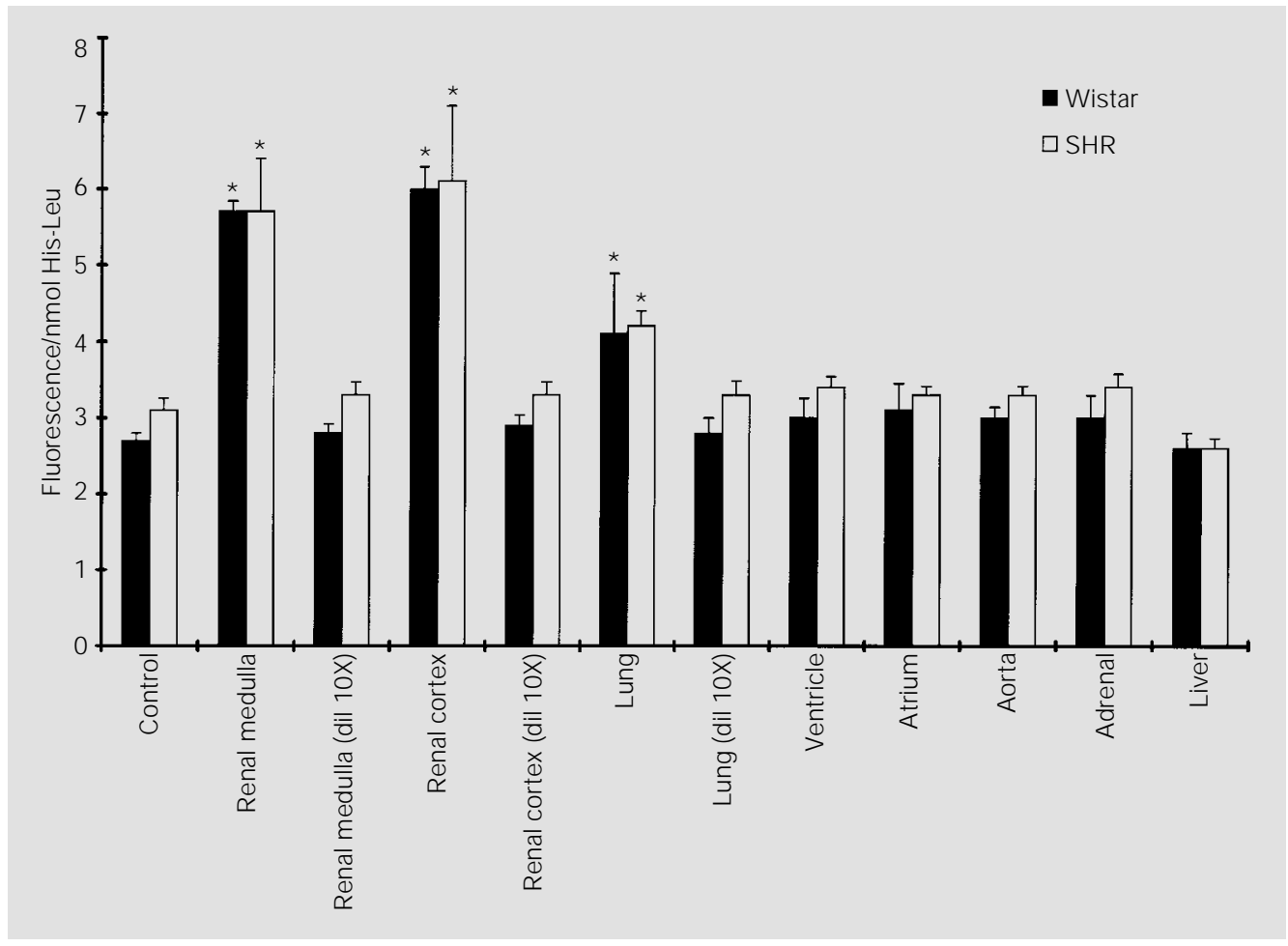


$100 \mu \mathrm{M}$ PCMB. This concentration of PCMB was chosen from a range tested $(0-2 \mathrm{mM})$ because it produced the highest inhibition of dipeptidase activity without affecting ACE activity. Dipeptidase activity observed in sodium BB and sodium PB is shown in Table 2. In the presence of sodium PB (Table 2), dipeptidase activity was detected in kidney $(50 \%)$, ventricle $(8 \%)$, serum $(5 \%)$ and liver $(65 \%)$. PCMB $(100 \mu \mathrm{M})$ in the incubation medium abolished His-Leu hydrolysis in these tissues. In contrast, in BB (Table 2) the dipeptidase activity, which was detected only in the liver ( $75 \%$ of His-Leu was hydrolyzed), could be partially (38\%) blocked by PCMB. In addition to the difference in dipeptidase activity, it is interesting to note that the specific activity of ACE determined using $\mathrm{BB}$ was consistently higher than with PB (Table 3).
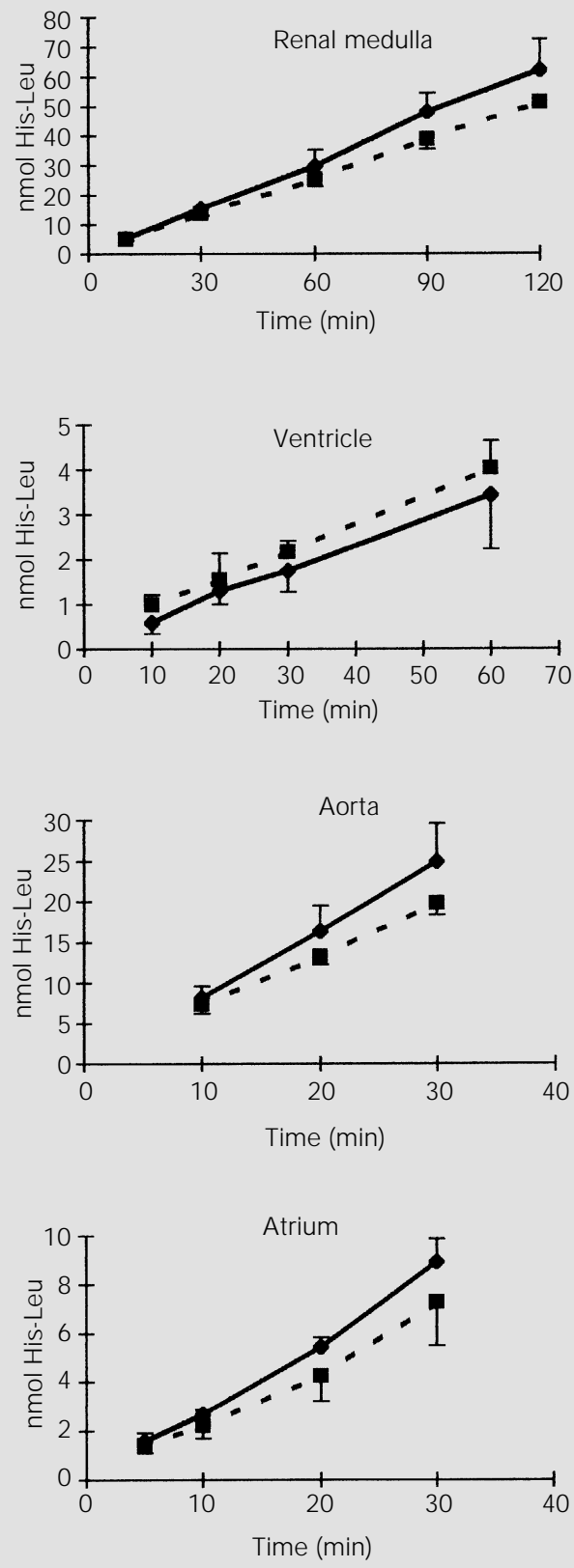
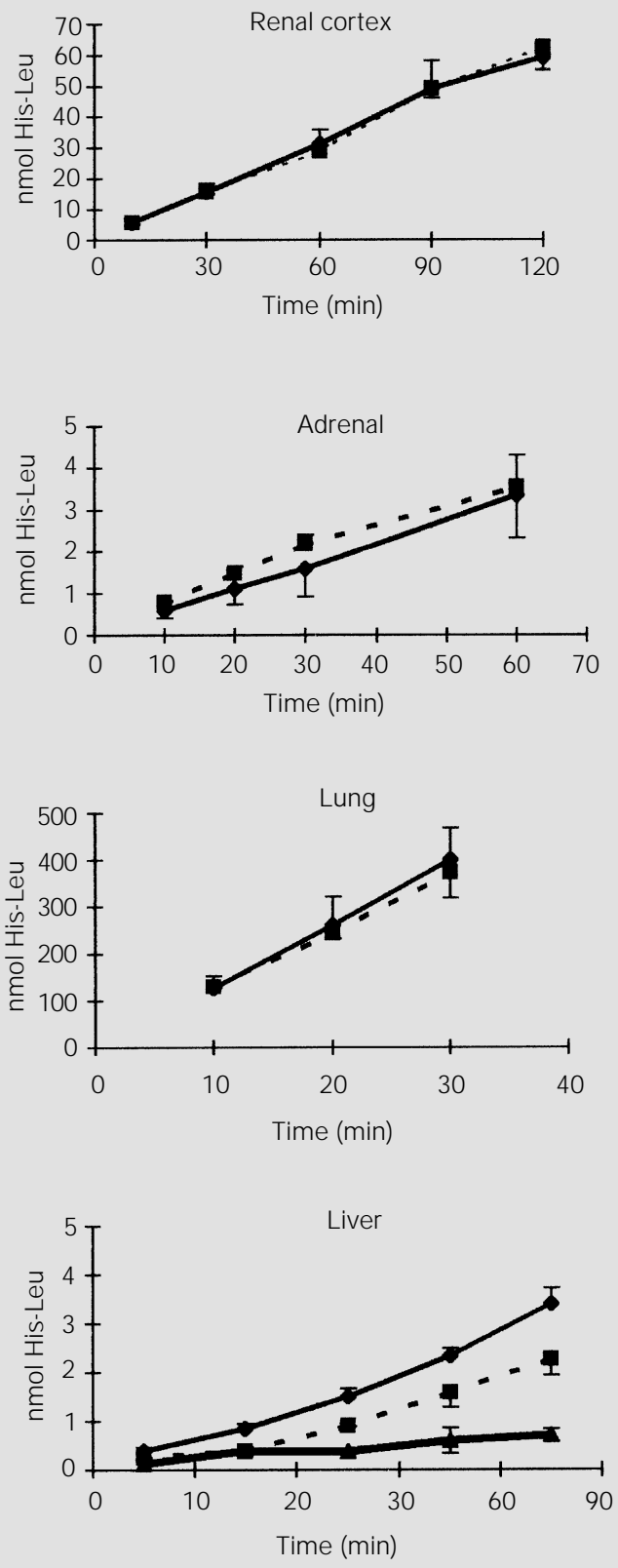

Figure 2 - Effect of incubation time on the formation of the HisLeu product by different tissue homogenates. His-Leu product formation was detected as described in Material and Methods. Data are reported as the mean \pm SD of three independent experiments for SHR (squares) and Wistar (lozenges) rats. The effect of $100 \mu \mathrm{M}$ PCMB treatment on the activity of liver homogenate is indicated by the triangles. 
Figure 3 - Effect of protein concentration in the assay medium on the formation of the His-Leu product by different tissue homogenates. The assay was carried out for $15 \mathrm{~min}$ (lung, and renal cortex and medulla) or 30 min (other tissues) as described in Material and Methods. Data are reported as the mean \pm SD of three independent experiments for SHR (squares) and Wistar (lozenges) rats.
The effect of release of the enzyme from the membranes was tested using the detergent Triton X-100. The ACE activity of lung homogenate increased $20 \%$ after treatment with $0.1 \%$ Triton $\mathrm{X}-100(\mathrm{P}<0.05)$ while no differences were detected in the other tissues (results not shown).

The effect of different times and temperatures of storage on ACE activity in tis- sue homogenates was tested (Table 4). To this end, the homogenates were stored at $-20^{\circ}$ or $-70^{\circ} \mathrm{C}$ for 7 and 30 days. The enzyme activity was stable when stored at both temperatures for up to 30 days.

Finally, ACE activity was compared among the different tissues from SHR and Wistar rats from our colony. ACE activity was lower in renal cortex, ventricle, atrium
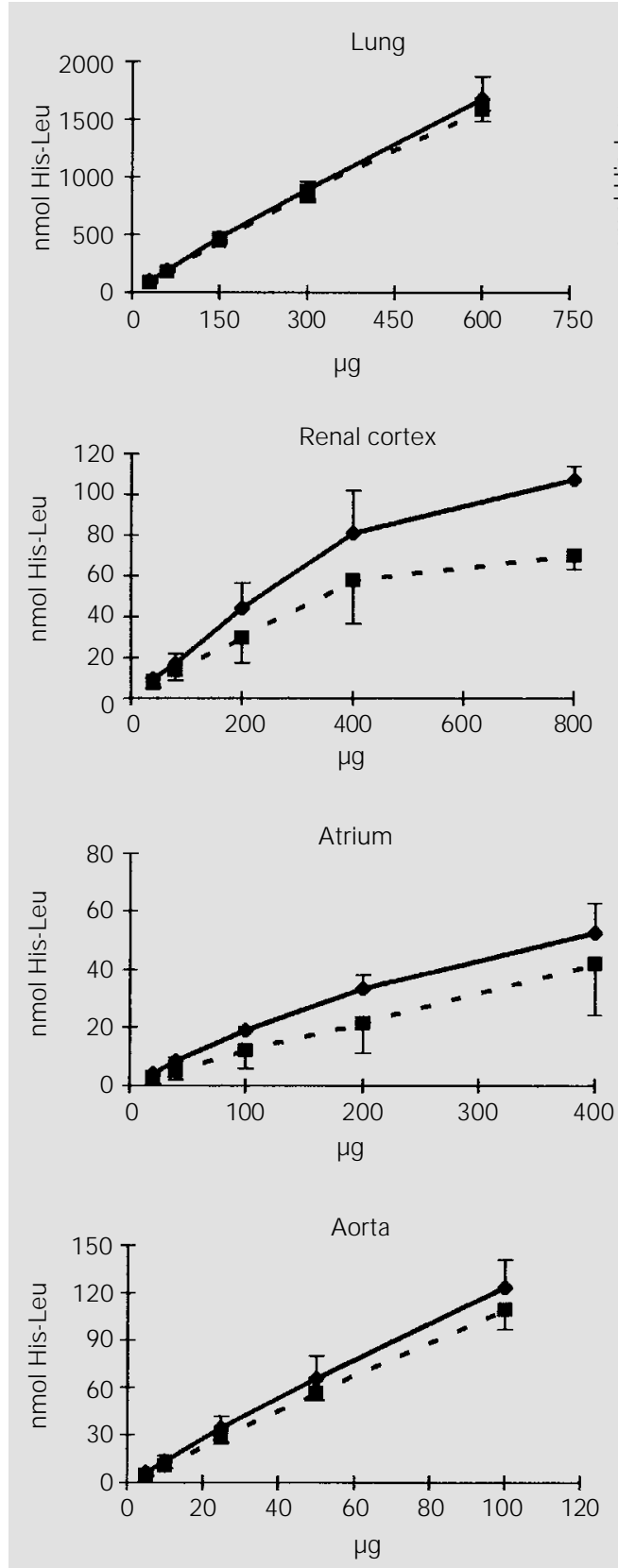
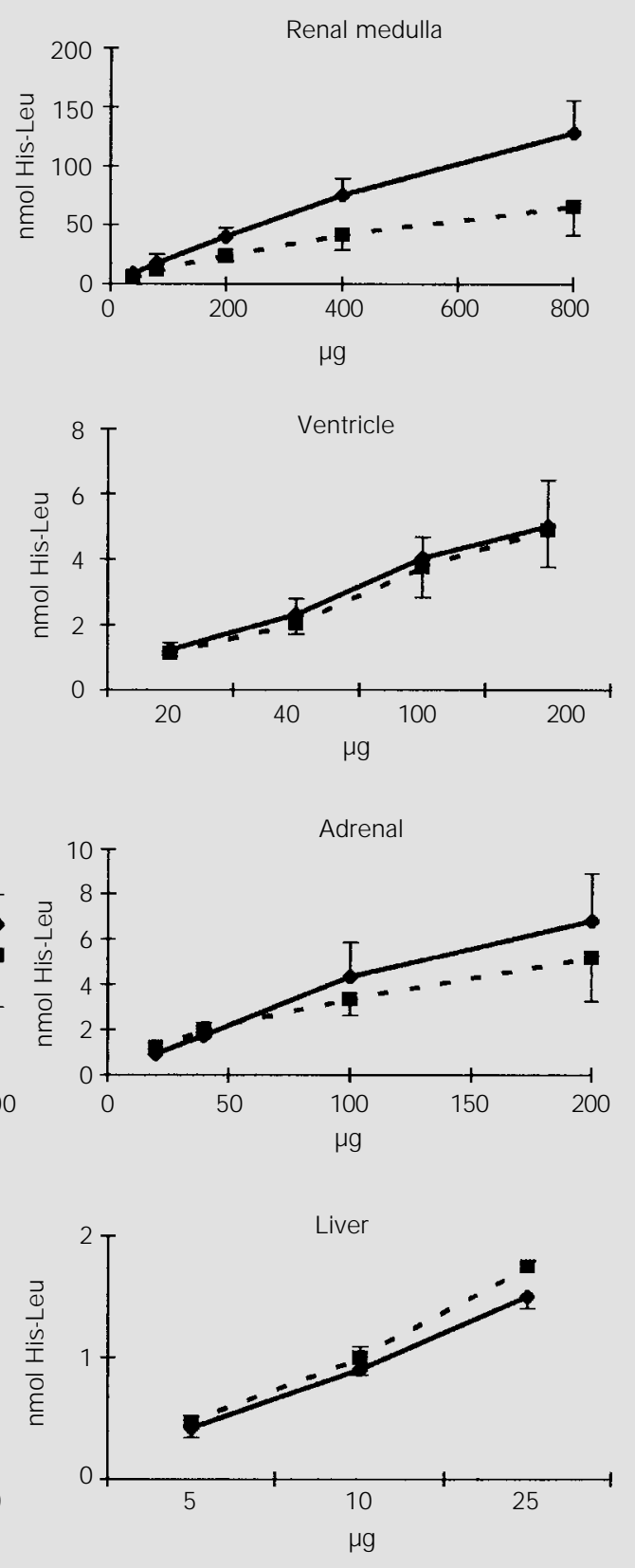
and serum, similar in renal medulla, adrenal and liver and higher in lung and aorta when Wistar tissues were compared to equivalent SHR tissues (Table 5).

\section{Discussion}

The study of tissue ACE is relevant because several lines of evidence indicate that it may be associated with the development of cardiac and vascular hypertrophy (14). However, depending on the buffers used, the various methods for determination of ACE activity usually yield different results.

The fluorimetric detection of the dipeptide His-Leu is one of the most sensitive nonisotopic procedures for measuring ACE activity using synthetic substrates such as Hip-

Table 1 - Measurement of dipeptidase activity.

Tissue homogenates from SHR and Wistar rats were incubated for 30 min with 31 nmol His-Leu. Data are reported as the relative fluorescence of the incubated product and the values obtained at time zero (control). Data indicate the mean \pm SD of three independent experiments. Only liver homogenate presented dipeptidase activity. The effect of $100 \mu \mathrm{M} \rho$-chloromercuribenzoic acid (PCMB) on the dipeptidase activity is shown. $* \mathrm{P}<0.01$ compared to incubated (-) PCMB (Student t-test).

\begin{tabular}{|c|c|c|c|c|}
\hline \multirow[t]{2}{*}{ Tissues } & \multicolumn{2}{|c|}{ Wistar } & \multicolumn{2}{|c|}{ SHR } \\
\hline & Control & Incubated & Control & Incubated \\
\hline Renal medulla & $5.7 \pm 0.09$ & $5.8 \pm 0.04$ & $5.7 \pm 0.09$ & $5.7 \pm 0.06$ \\
\hline Renal cortex & $5.8 \pm 0.08$ & $5.7 \pm 0.14$ & $5.7 \pm 0.05$ & $5.6 \pm 0.10$ \\
\hline Lung & $5.7 \pm 0.01$ & $5.8 \pm 0.04$ & $5.7 \pm 0.07$ & $5.8 \pm 0.05$ \\
\hline Ventricle & $5.5 \pm 0.05$ & $5.3 \pm 0.09$ & $5.5 \pm 0.07$ & $5.2 \pm 0.05$ \\
\hline Aorta & $5.7 \pm 0.02$ & $5.7 \pm 0.02$ & $5.9 \pm 0.01$ & $5.9 \pm 0.02$ \\
\hline Atrium & $5.5 \pm 0.05$ & $5.3 \pm 0.03$ & $5.8 \pm 0.05$ & $5.6 \pm 0.03$ \\
\hline Adrenal & $5.5 \pm 0.04$ & $5.5 \pm 0.03$ & $5.7 \pm 0.03$ & $5.5 \pm 0.09$ \\
\hline Liver (-) PCM B & $5.8 \pm 0.05$ & $2.0 \pm 0.09$ & $5.8 \pm 0.05$ & $2.3 \pm 0.03$ \\
\hline Liver (+) PCMB & $5.8 \pm 0.05$ & $3.8 \pm 0.12^{*}$ & $5.8 \pm 0.05$ & $3.8 \pm 0.12 *$ \\
\hline
\end{tabular}

Table 2 - Effect of buffer and $\rho$-chloromercuribenzoic acid (PCMB) on the dipeptidase activity of tissue homogenates from Wistar rats.

The homogenates $(20 \mu \mathrm{l})$ and serum $(10 \mu \mathrm{l})$ were incubated for $30 \mathrm{~min}$ with $62 \mathrm{nmol}$ His-Leu in the presence and absence of $100 \mu \mathrm{M}$ PCMB. Data indicate the relative fluorescence of the incubated product and the values obtained at time zero (control). Data represent the mean \pm SD of three independent experiments. $* \mathrm{P}<0.01$ compared to control (Student t-test).

\begin{tabular}{|c|c|c|c|c|}
\hline \multirow[t]{2}{*}{ Tissues } & \multicolumn{2}{|c|}{ Borate buffer } & \multicolumn{2}{|c|}{ Phosphate buffer } \\
\hline & Control & Incubated & Control & Incubated \\
\hline Lung (+) PCMB & $14.9 \pm 0.1$ & $14.9 \pm 0.06$ & $14.6 \pm 0.33$ & $14.6 \pm 0.30$ \\
\hline Lung (-) PCMB & $15.0 \pm 0.2$ & $14.4 \pm 0.86$ & $14.7 \pm 0.19$ & $14.8 \pm 0.57$ \\
\hline Serum (+) PCMB & $11.8 \pm 0.3$ & $12.1 \pm 0.09$ & $12.7 \pm 0.05$ & $11.9 \pm 0.09$ \\
\hline Serum (-) PCMB & $13.6 \pm 0.2$ & $13.4 \pm 0.25$ & $13.3 \pm 0.09$ & $11.2 \pm 0.27 *$ \\
\hline Kidney (+) PCMB & $14.7 \pm 0.1$ & $13.8 \pm 0.10$ & $14.7 \pm 0.13$ & $13.8 \pm 0.24$ \\
\hline Kidney (-) PCMB & $14.7 \pm 0.1$ & $13.5 \pm 0.21$ & $14.7 \pm 0.11$ & $7.57 \pm 0.41 *$ \\
\hline Ventricle (+) PCMB & $12.4 \pm 0.2$ & $12.4 \pm 0.15$ & $12.5 \pm 0.05$ & $12.3 \pm 0.07$ \\
\hline Ventricle (-) PCMB & $12.9 \pm 0.3$ & $11.7 \pm 0.47$ & $12.7 \pm 0.05$ & $9.8 \pm 0.18^{*}$ \\
\hline Liver (+) PCMB & $12.2 \pm 0.5$ & $7.6 \pm 0.62 *$ & $12.5 \pm 0.05$ & $11.8 \pm 0.02$ \\
\hline Liver (-) PCMB & $13.8 \pm 0.2$ & $3.5 \pm 0.20^{*}$ & $14.2 \pm 0.22$ & $5.0 \pm 0.34^{*}$ \\
\hline
\end{tabular}


His-Leu or the natural substrate, Ang I. According to Santos et al. (10), the use of sodium BB instead of PB increased the $V_{\max }$ and reduced the $K_{\mathrm{m}}$ of the enzyme when measured in rat serum. Santos et al. (10) also observed lower dipeptidase activity against the His-Leu substrate when BB was used. The $V_{\max }$ of this enzyme was reduced and the $K_{\mathrm{m}}$ increased. These results indicate a protection of the His-Leu dipeptide used to measure ACE activity by the buffer, with reduced hydrolysis by the dipeptidases. Hydrolysis of His-Leu leads to the underestimation of ACE activity due to the lower fluorescence of the free amino acids leucine and histidine (10). In the present study, we extended these

Table 3 - Effect of borate and phosphate buffer on the ACE activity of Wistar rat tissue homogenates.

The enzyme activity was assayed as described in Material and Methods. Results are reported as nmol His-Leu min-1 $^{-1}$ mg protein $^{-1}$ or nmol His-Leu $\mathrm{min}^{-1} \mathrm{ml}^{-1}$. Data represent the mean \pm SD of three independent experiments. $* \mathrm{P}<0.01$ compared to borate buffer (Student t-test).

\begin{tabular}{lcc}
\hline Tissues & Borate buffer & Phosphate buffer \\
\hline Lung & $141.3 \pm 4.8$ & $28.6 \pm 2.1^{*}$ \\
Serum & $131.0 \pm 4.0$ & $28.0 \pm 2.3^{*}$ \\
Kidney & $8.6 \pm 1.7$ & $1.20 \pm 0.18^{*}$ \\
Ventricle & $1.5 \pm 0.12$ & $0.16 \pm 0.013^{*}$ \\
Liver & $0.15 \pm 0.017$ & $0.023 \pm 0.0054^{*}$
\end{tabular}

observations so as to optimize the conditions of the assay to determine ACE activity in several rat tissues.

Considering the differences in the peptidase content of tissues, it was necessary to investigate their possible interference with the detection of the His-Leu product. The interference was produced by lung and kidney medulla and cortex homogenates and was successfully resolved by diluting the homogenate 10 times with the assay buffer.

The specificity of Hip-His-Leu hydrolysis by ACE activity was demonstrated in the presence of the ACE inhibitor enalaprilat. This compound essentially abolished ACE activity at $3-\mu \mathrm{M}$ concentration.

The linearity of the reaction was also evaluated as a function of time of incubation and protein concentration. Linearity was obtained for all tissues using $20 \mu \mathrm{l}$ of the homogenate and a time of incubation of 30 min. Lung and aorta required incubation times of $15 \mathrm{~min}$. This is in accordance with previous reports showing a high ACE activity in lung and aorta $(15,16)$.

Homogenate stability was maintained up to $1 \mathrm{~h}$ under the assay conditions when using BB.

Dipeptidase activity varied according to the tissue homogenates and the buffer used. The high dipeptidase activity observed in the

Table 4 - Stability of ACE activity in tissue homogenates stored at $-20^{\circ}$ or $-70^{\circ} \mathrm{C}$ for 7 or 30 days.

Analysis was performed on fresh and stored tissue homogenates. The enzyme activity was assayed as described in Material and Methods. Results are expressed as nmol His-Leu min $^{-1}$ mg protein-1. Data represent the mean \pm SD of three independent experiments.

\begin{tabular}{|c|c|c|c|c|c|}
\hline \multirow[t]{2}{*}{ Tissues } & \multirow[t]{2}{*}{ Day 0} & \multicolumn{2}{|c|}{7 Days } & \multicolumn{2}{|c|}{30 Days } \\
\hline & & $-20^{\circ} \mathrm{C}$ & $-70^{\circ} \mathrm{C}$ & $-20^{\circ} \mathrm{C}$ & $-70^{\circ} \mathrm{C}$ \\
\hline Renal medulla & $8.6 \pm 1.0$ & $6.6 \pm 1.1$ & $7.0 \pm 1.0$ & $6.8 \pm 0.3$ & $6.1 \pm 0.9$ \\
\hline Renal cortex & $7.1 \pm 0.3$ & $7.0 \pm 1.6$ & $6.3 \pm 1.0$ & $6.4 \pm 0.5$ & $6.4 \pm 0.8$ \\
\hline Lung & $172.4 \pm 6.1$ & $186.7 \pm 10.7$ & $179.3 \pm 22.9$ & $170.3 \pm 11.9$ & $162.1 \pm 8.3$ \\
\hline Ventricle & $1.8 \pm 0.3$ & $1.6 \pm 0.3$ & $1.6 \pm 0.2$ & $1.8 \pm 0.2$ & $1.7 \pm 0.2$ \\
\hline Aorta & $121.8 \pm 5.5$ & $115.0 \pm 11.4$ & $107.6 \pm 7.8$ & $110.5 \pm 7.9$ & $104.0 \pm 4.8$ \\
\hline Atrium & $10.2 \pm 1.6$ & $10.7 \pm 2.3$ & $10.0 \pm 1.4$ & $10.9 \pm 1.7$ & $10.2 \pm 1.6$ \\
\hline Adrenal & $1.1 \pm 0.1$ & $2.0 \pm 0.4$ & $1.2 \pm 0.2$ & $1.1 \pm 0.1$ & $1.1 \pm 0.1$ \\
\hline Liver & $0.1 \pm 0.0$ & $0.1 \pm 0.0$ & $0.1 \pm 0.0$ & $0.1 \pm 0.0$ & $0.1 \pm 0.0$ \\
\hline
\end{tabular}


liver was partially inhibited by $100 \mu \mathrm{M}$ PCMB. Interestingly, in both SHR and Wistar rats, dipeptidase activity measured with $\mathrm{BB}$ was essentially absent in all tissue homogenates, except liver. In contrast, PB displayed dipeptidase activity in several other tissue homogenates. As was observed for serum, BB successfully minimized the interference of dipeptidase activity in the assay for rat tissues (10). The mechanism of the inhibitory effect of high ionic strength $(\mathrm{NaCl})$ combined with sodium $\mathrm{BB}$ on the His-Leu dipeptidase activity is not known.

The possibility of an enhancement of ACE activity produced by the detergent Triton X-100 was also investigated. It is thought that the detergent can increase activity by displacing the enzyme from the membranes (3). In our protocol only the lung homogenate showed a significant increase of ACE activity, indicating no need for such treatment before the assay for the other tissues.

Although the objective of this study was not to compare ACE activity among rat strains, we observed that ACE activity varied when different tissues were compared between SHR and Wistar rats from the colony maintained at our facility (Heart Institute/ USP). These results are in general agreement with findings from other laboratories. However, the discrepancies reported (15) may be explained, at least in part, by different assay conditions and genetic variability in the strains of the animals studied.

In summary, the results presented here indicate that the use of BB for the fluorimet-
Table 5 - Determination of the ACE activity in several tissues of Wistar and SHR rats.

The enzyme activity was assayed as described in Material and Methods. Results are reported as $\mathrm{nmol}$ His-Leu min $^{-1} \mathrm{mg}_{\text {protein }}{ }^{-1}$ or nmol His-Leu $\mathrm{min}^{-1} \mathrm{ml}^{-1}$. Data represent the mean $\pm \mathrm{SD}$ of three independent experiments. $* \mathrm{P}<0.05$ compared to Wistar rat tissue (Student t-test).

\begin{tabular}{lrr} 
Tissues & \multicolumn{1}{c}{ Wistar } & \multicolumn{1}{c}{ SHR } \\
\hline Renal medulla & $8.5 \pm 1.2$ & $8.3 \pm 0.4$ \\
Renal cortex & $7.1 \pm 0.4$ & $6.0 \pm 0.4^{*}$ \\
Lung & $172.4 \pm 7.5$ & $228.9 \pm 26.2^{*}$ \\
Ventricle & $1.8 \pm 0.4$ & $0.8 \pm 0.0^{*}$ \\
Atrium & $10.2 \pm 1.9$ & $5.9 \pm 0.9^{*}$ \\
Aorta & $121.8 \pm 6.7$ & $136.8 \pm 5.9^{*}$ \\
Adrenal & $1.1 \pm 0.1$ & $1.1 \pm 0.2$ \\
Liver & $0.1 \pm 0.0$ & $0.1 \pm 0.0$ \\
Serum & $127.6 \pm 1.5$ & $92.9 \pm 9.7^{*}$
\end{tabular}

ric detection of the His-Leu dipeptide is a simple, sensitive and reliable method for the determination of ACE activity in rat tissue samples. Although the sensitivity of this assay for the determination of ACE activity in subcellular fractions was not investigated, the data obtained with the homogenates suggest that this method may be also applicable to subcellular fraction analysis. Precise ACE activity measurements combined with molecular biology approaches will allow a better understanding of the regulatory mechanisms involved in the control of circulating and tissue ACE activity. It is important to understand how the renin-angiotensin system is regulated under different physiological and pathological conditions.

\section{References}

1. Cushman DW \& Cheung HS (1971). Spectrophotometric assay and properties of the angiotensin-converting enzyme of rabbit lung. Biochemical Pharmacology, 20: 1637-1648.

2. Yang HYT, Erdös EG \& Levin Y (1972). Characterization of a dipeptide hydrolase (kininase II: angiotensin I converting enzyme). J ournal of Pharmacology and Ex- perimental Therapeutics, 117: 291-300.

3. Welsch C, Grima M, Giesen EM, Helwing J J , Barthelmebs M, Coquard C \& Imbs J L (1989). Assay of tissue angiotensin converting enzyme. J ournal of Cardiovascular Pharmacology, 14 (Suppl 4): S26-S31.

4. Dzau VJ (1988). Circulating versus local reninangiotensin system in cardiovascular homeostasis. Circulation, 77 (Suppl I): I-4-I-13.
5. Piquilloud $Y$, Reinharz A \& Roth M (1970). Studies on the angiotensin converting enzyme with different substrates. Biochimica et Biophysica Acta, 206: 136-142.

6. Bakhle YS (1974). Converting enzyme: in vitro measurement and properties. In: Page IH \& Bumpus FM (Editors), Angiotensin. Springer-Verlag, New York.

7. Soffer RL (1976). Angiotensin-converting 
enzyme and the regulation of vasoactive peptides. Annual Review of Biochemistry, 45: 73-93.

8. Friedland J \& Silverstein E (1976). A sensitive fluorimetric assay for serum angiotensin-converting enzyme. American J ournal of Clinical Pathology, 66: 416-424.

9. Ondetti MA \& Cushman DW (1982). Enzymes of the renin-angiotensin system and their inhibitors. Annual Review of Biochemistry, 51: 283-308.

10. Santos RAS, Krieger EM \& Greene LJ (1985). An improved fluorometric assay of rat serum and plasma converting enzyme. Hypertension, 7: 244-252.

11. Soffer RL (1981). Angiotensin-converting enzyme. In: Soffer RL (Editor), Biochemical Regulation of Blood Pressure. J ohn
Wiley $\&$ Sons, New York.

12. Unger T, Schull B, Rascher W, Lang RE \& Ganten D (1982). Selective activation of the converting enzyme inhibitor MK 421 and comparison of its active diacid form with captopril in different tissues of the rat. Biochemical Pharmacology, 31: 30633070.

13. Bradford MM (1976). A rapid and sensitive method for the quantitation of microgram quantities of protein utilizing the principle of protein-dye binding. Analytical Biochemistry, 72: 248-254.

14. Shunkert H, Dzau VJ , Tang SS, Hirsh AT, Apstein CS \& Lorell BH (1990). Increased rat cardiac angiotensin converting enzyme activity and mRNA expression in pressure overload left ventricular hypertrophy: ef- fects on coronary resistance, contractility, and relaxation. J ournal of Clinical Investigation, 86: 1913-1920.

15. Grima M, Welsch C, Giesen-Crouse EM Coquard $C$, Barthelmebs $M$ \& Imbs J L (1990). Age-related variations in tissue angiotensin converting enzyme activities: comparison between spontaneously hypertensive and Wistar-Kyoto rats. J ournal of Hypertension, 8: 697-702.

16. Okunishi $\mathrm{H}$, Kawamoto $\mathrm{T}$, Kurobe $\mathrm{Y}$, Oka Y, Ishii K, Tanaka T \& Miyazaki M (1991). Pathogenic role of vascular angiotensinconverting enzyme in the spontaneously hypertensive rat. Clinical and Experimental Pharmacology and Physiology, 18: 649659. 